\title{
GENETIC DIVERSITY AMONG MICROSYMBIONTS OF Lathyrus, Vicia, Oxytropis AND Astragalus LEGUME SPECIES FROM BAIKAL REGION
}

\section{I.G. KUZNETSOVA ${ }^{1}$, A.L. SAZANOVA ${ }^{1}$, V.I. SAFRONOVA ${ }^{1}$, A.G. PINAEV ${ }^{1}$,} A.V. VERKHOZINA ${ }^{2}$, N.Yu. TIKHOMIROVA ${ }^{1}$, Yu.S. OSLEDKIN ${ }^{1}$, A.A. BELIMOV ${ }^{1}$

${ }^{1}$ All-Russian Research Institute for Agricultural Microbiology, Federal Agency of Scientific Organizations, 3, sh. Podbel'skogo, St. Petersburg, 196608 Russia, e-mail v.safronova@rambler.ru;

${ }^{2}$ Siberian Institute of Plant Physiology and Biochemistry, Federal Agency of Scientific Organizations, 132, ul. Lermontova, Irkutsk, 664033 Russia

Acknowledgements:

Authors are thankful to SIPPB SB RAS employees L.E. Makarova for her help in organizing the expedition to the Chivyrkuy Gulf Coast and A.A. Kiseleva for plant identification.

Supported in part by Russian Science Foundation (Agreement number 14-26-00094) (sequencing of the isolates from Vicia baicalensis)

Received March 30, 2015

\section{Abstract}

Rhizobia are Gram-negative soil microorganisms that form intracellular nitrogen-fixing symbiosis with leguminous plants. Investigations of symbiotic systems with the participation of endemic or relict species have a particular importance for understanding of the evolution of plantmicrobe interactions. The purpose of our work was to create a representative collection of microsymbionts of endemic Baikal legumes, as well as to estimate their biodiversity. The study of taxonomic positions of 69 isolates from root nodules Lathyrus humilis, Vicia baicalensis, Astragalus mongholicus and Oxytropis sylvatica was conducted. For primary identification of these isolates the methods of ITS-RFLP analysis was used that divided strains into 33 groups with identical DNAprofile. Then the taxonomy positions of isolates were determined by the $16 \mathrm{~S}$ rRNA gene (rrs) and ITS region sequencing. Phylogenetic analysis revealed the considerable genetic diversity among microsymbionts of plants studied. Rhizobial isolates belonged to 5 genera: Rhizobium (family Rhizobiaceae), Mesorhizobium and Phyllobacterium (family Phyllobacteriaceae), Bosea and Tardiphaga (family Bradyrhizobiaceae). In addition, non-rhizobial isolates belonging to the genera Herbiconiux, Leifsonia, Burkholderia and Stenotrophomonas were obtained. It is known that some species of these genera may be present in the nodules of legumes, but also be inhabitants of rhizosphere or phyllosphere of different plants. The presence of atypical rhizobial microsymbionts in the studied plants was noted, which may indicate the active formation of relationships between partners in the legumerhizobial systems of Baikal region.

Keywords: legumes of Baikal region, taxonomy of rhizobia, ribosomal genes sequencing.

Nodule bacteria (Rhizobia) belong to a large genetically diverse group of Gram-negative soil microorganisms that form intracellular nitrogen-fixing symbiosis with legumes. One of the urgent tasks of modern biotechnology is the study of mechanisms of interaction of legumes with rhizobia, required for evidence-based selection of highly effective plant-microbe systems [1].

Investigations of symbiotic systems with the participation of endemic or relict species have a particular importance for understanding of the evolution of plant-microbe interactions. These unique objects include Baikal legumes, such as low-growing vetchling (Lathyrus humilis), a Late Pleistocene relict of the South Siberian-Severouralsk area [2]; Mongolian milk vetch (Astragalus mongholicus), a rare medicinal plant [3, 4]; Baikal endemics Baikal pea (Vicia baicalensis) and forest oxytrope (Oxytropis sylvatica) [5].

Few data on Astragalus microsymbionts show a great diversity of these microorganisms belonging to different genera of order Rhizobiales: Rhizobium, Sinorhizobium, Bradyrhizobium, and Mesorhizobium [6-9]. Vetch- 
ling and pea species are nodulated with bacteria Rhizobium leguminosarum bv. viciae [10-12], and rhizobia and mesorhizobia strains are described among oxytrope microsymbionts [7, 13]. However, microsymbionts of Baikal plants belonging to these genera have not been studied.

The purpose of this study was to create a representative collection of microsymbiont strains of endemic Baikal legumes (low-growing vetchling, Mongolian milk vetch, Baikal pea, and forest oxytrope) and to estimate their taxonomic position using the method of $16 \mathrm{~S}$ rDNA and ITS-region sequencing.

Technique. A total of 69 strains isolated as described [14] from root nodules of low-growing vetchling Lathyrus humilis, Baikal pea Vicia baicalensis (two populations of each species) as well as Mongolian milk vetch Astragalus mongholicus and forest oxytrope Oxytropis sylvatica (one population of each species) which grow on the Chivyrkuy coast Bay (Baikal) were studied. Strains were grown on yeast mannitol agar (YMA) at $28{ }^{\circ} \mathrm{C}$ [7].

For primary identification of strain intraspecific diversity, RFLP 16S and 23S rRNA (ITS-region) sequencing analysis was performed. Amplified DNA was digested with MspI, and the resulting DNA fragments were separated by electrophoresis in the standard mode [15]. Species affiliation of strains was determined by $16 \mathrm{~S}$ rRNA gene (rrs) sequencing. The taxonomy position of Bosea nodule bacteria was specified using the more variable ITS-region sequencing method.

To amplify 16S rDNA (about $1500 \mathrm{bp}$ ), the fD1 (5'-AGAGTTTGATCCTGGCTCAG-3') and rD1 (5'-AAGGAGGTG-ATCCAGCC-3') primers were used, to amplify the ITS-region (800 bp), the FGPS1490-72 (5'-TGCGGCTGGATCCCCTCCTT-3') and FGPL-132 (5'-CCGGGTTTCCCCATTCGG-3') primers were used. The resulting PCR product was gel purified [15] for subsequent sequencing.

The search for homologous sequences was performed using the GenBank database (BLAST program). The phylogenetic tree was constructed using the MEGA v. 4.0.2 program (Neighbor-Joining method). Sequence pairs were compared using the number of different nucleotides.

Results. The strains used in the study are summarized in the Table.

Taxonomic structure of microsymbiont strains isolated from root nodules in endemic Baikal legumes (according to rrs and ITS-region sequencing)

\begin{tabular}{|c|c|c|c|c|}
\hline \multirow[b]{2}{*}{$\begin{array}{l}\text { Microsymbiont } \\
\text { species }\end{array}$} & \multicolumn{4}{|c|}{ Legume microsymbiont No. } \\
\hline & $\begin{array}{l}\text { low-growing } \\
\text { vetchling } \\
\text { Lathyrus humilis }\end{array}$ & $\begin{array}{l}\text { Mongolian milk } \\
\text { vetch Astragalus } \\
\text { mongholicus } \\
\end{array}$ & $\begin{array}{l}\text { Baikal pea } \\
\text { Vicia baicalensis }\end{array}$ & $\begin{array}{l}\text { Forest oxytrope } \\
\text { Oxytropis sylvatica }\end{array}$ \\
\hline Rhizobium sp. & $2 / 5(1), 2 / 12 \mathrm{M}$ & - & - & - \\
\hline $\begin{array}{l}\text { Rhizobium } \\
\text { leguminosarum } \\
\text { bv. trifolii }\end{array}$ & $1 / 10 \mathrm{~K}, 2 / 10 \mathrm{~K}$ & - & $\begin{array}{l}11 / 2,11 / 3 \mathrm{~K}, 11 / 4 \mathrm{M}, \\
11 / 7 \mathrm{~K}, 11 / 12 \mathrm{M}, 11 / 19, \\
11 / 20,11 / 21,11 / 22, \\
11 / 23,11 / 24 \mathrm{~K}, 11 / 24 \mathrm{M}, \\
11 / 25,11 / 33,11 / 34 \mathrm{~K}, \\
11 / 34 \mathrm{M}, 11 / 35,11 / 36, \\
11 / 37 \mathrm{~K}, 11 / 37 \mathrm{M}, 11 / 38, \\
11 / 39,11 / 42 \mathrm{~K}, 11 / 42 \mathrm{M}, \\
11 / 43 \mathrm{~K}, 11 / 44 \mathrm{~K}, 11 / 44 \mathrm{M}, \\
11 / 45 \mathrm{~K}, 11 / 46,11 / 47 \mathrm{~K}, \\
11 / 47 \mathrm{M}, 11 / 48 \mathrm{~K}, 11 / 48 \mathrm{M}, \\
13 / 3,13 / 4,13 / 6 \mathrm{M}, 13 / 7, \\
13 / 8 \mathrm{~K}, 13 / 9 \mathrm{M}, 13 / 11\end{array}$ & 12/13M, 12/16K \\
\hline Mesorhizobium & & & & \\
\hline metallidurans & - & $3 / 14 \mathrm{C} 1,3 / 14 \mathrm{C} 2$ & - & - \\
\hline Mesorhizobium ciceri & $2 / 13 \mathrm{~K}$ & - & - & - \\
\hline Tardiphaga robiniae & $1 / 11 \mathrm{M}$ & $\begin{array}{l}3 / 6 \mathrm{M}, \\
3 / 11 \mathrm{C}, 3 / 21(2)\end{array}$ & - & $12 / 11(1)$ \\
\hline Bosea sp. & - & $\begin{array}{l}3 / 5 \mathrm{M} \\
3 / 31 \mathrm{~K}\end{array}$ & - & $12 / 22 \mathrm{M}$ \\
\hline Bosea vaviloviae & - & $3 / 25$ & - & - \\
\hline
\end{tabular}




\begin{tabular}{|c|c|c|c|c|}
\hline Herbiconiux sp. & $\begin{array}{l}1 / 3 \mathrm{M}, 1 / 5 \mathrm{M}, \\
1 / 14 \mathrm{M}, 1 / 15 \mathrm{M}\end{array}$ & - & - & - \\
\hline Burkholderia sp. & - & $3 / 8 \mathrm{~K}$ & $13 / 5$ & - \\
\hline Leifsonia sp. & - & $3 / 23 \mathrm{M}, 3 / 27 \mathrm{~K}$ & & \\
\hline Stenotrophomonas sp. & - & $3 / 17$ & $11 / 7 \mathrm{M}$ & \\
\hline Phyllobacterium sp. & - & & $13 / 12 \mathrm{M}$ & \\
\hline
\end{tabular}

Note. Dashes mean the absence of isolates.

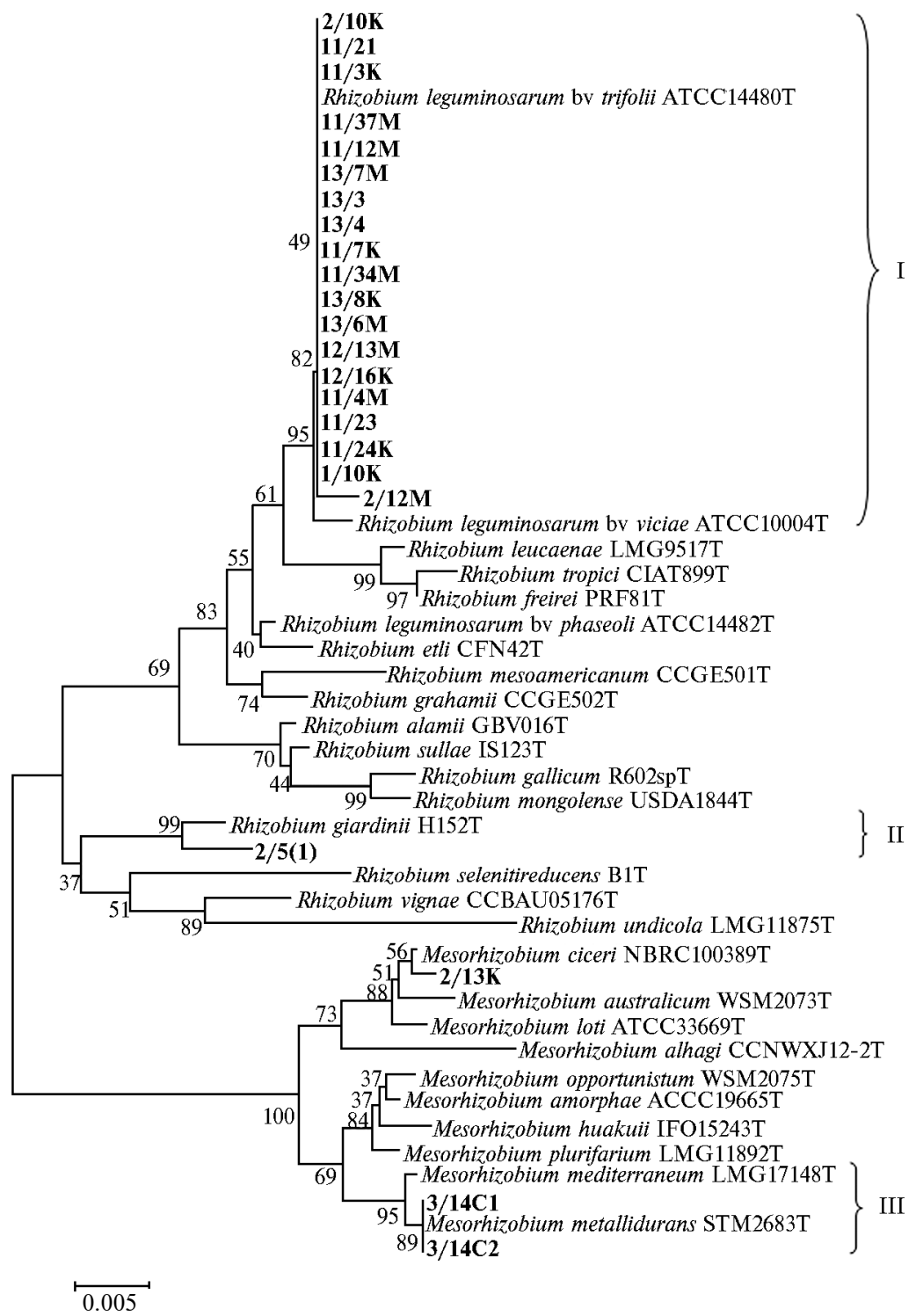

Fig. 1. Rrs-phylogram demonstrating the taxonomic position of genera Rhizobium and Mesorhizobium isolates. The tested strains are marked in bold. Letter «T» marks typical strains; I-III significantly different clusters.

Isolates were divided into two groups by their growth rate. In 9 strains, visible colonies were formed from the day 5 to 6 of growth on YMA medium, other strains formed colonies from the day 3 to 4 . Based on the results of ITS-region RFLP-analysis, studied isolates were divided into 33 groups with identical DNA profile. One species of each group was selected for rrs sequencing. Rrs sequencing analysis showed that 23 strains belonged to genera Rhizo- 
bium and Mesorhizobium and formed three significantly different clusters with the level of support of more than $95 \%$ (Fig. 1).

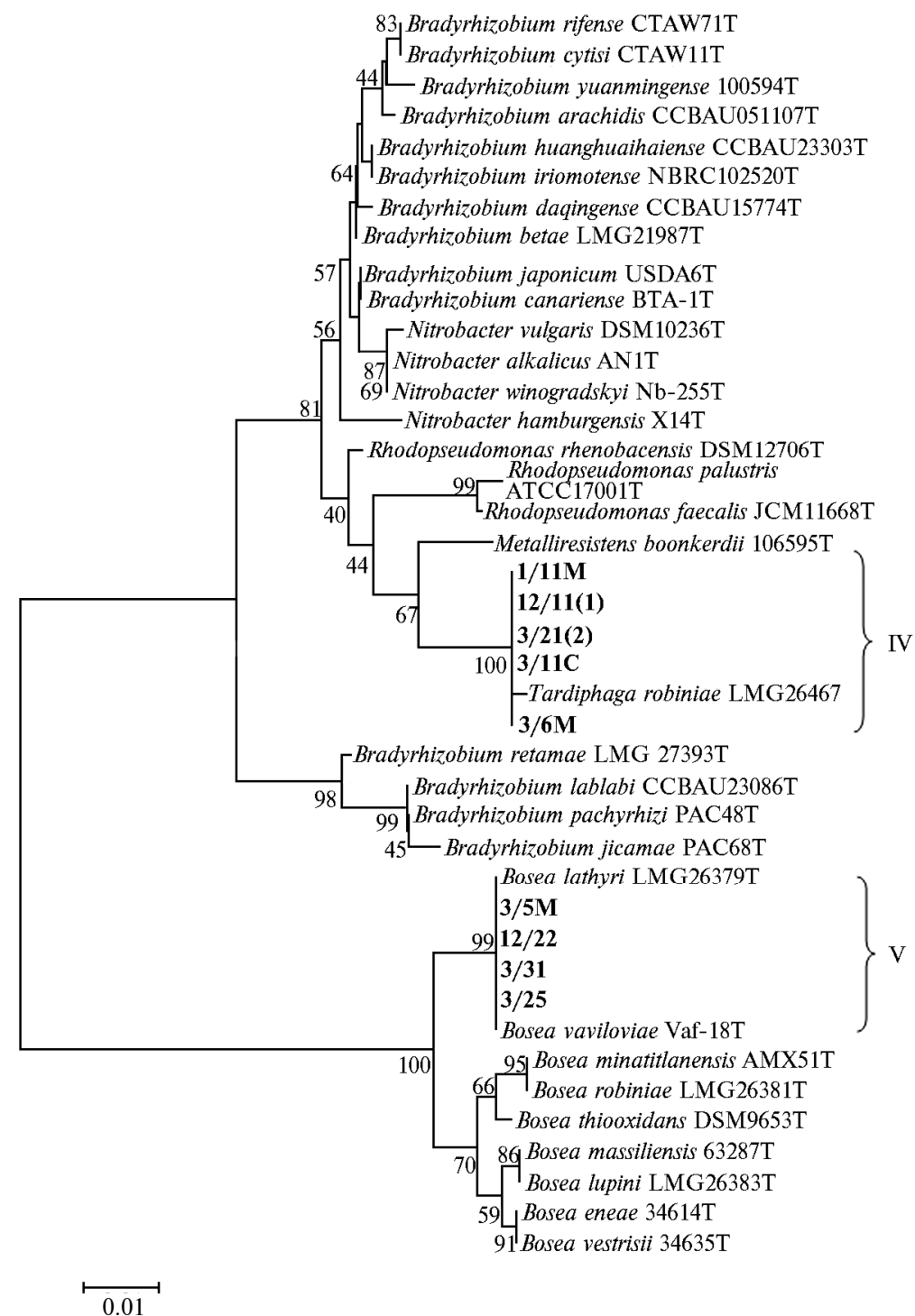

Fig. 2. Rrs-phylogram demonstrating the taxonomic position of isolates within the Bradyrhizobiaceae family. Tested strains are marked in bold. Letter «T» marks typical strains; IV, V significantly different clusters.

Cluster I included 19 strains isolated from low-growing vetchling, baikal pea and forest oxytrope (3,14 and 2 strains, respectively) and two typical strains $R$. leguminosarum bv. trifolii ATCC14480T and $R$. leguminosarum bv. viciae ATCC10004T. Based on the results of rrs sequencing (see Table), isolates $1 / 10 \mathrm{~K}, 2 / 10 \mathrm{~K}, 11 / 3 \mathrm{~K}, 11 / 4 \mathrm{M}, 11 / 7 \mathrm{~K}, 11 / 12 \mathrm{M}, 11 / 21,11 / 23,11 / 24 \mathrm{~K}$, $11 / 34 \mathrm{M}, 11 / 37 \mathrm{M}, 12 / 13 \mathrm{M}, 12 / 16 \mathrm{~K}, 13 / 3,13 / 4,13 / 6 \mathrm{M}, 13 / 7 \mathrm{M}$, and $13 / 8 \mathrm{~K}$ were identified as $R$. leguminosarum bv. trifolii (index of similarity to typical strain ATCC14480T was 99.7-99.9\%).

Cluster II was formed by strain $2 / 5(1)$ isolated from low-growing vetchling and typical strain H152T Rhizobium giardinii which has been described as microsymbiont strain [16]. However, since the similarity between these strains in gene rrs was $99.0 \%$ only, strain 2/5(1) was identified as 
Rhizobium sp. (see Table).

Three isolates were classified as Mesorhizobium (see Fig. 1, Table). Strains 3/14C1 and 3/14C2 (cluster III) isolated from Mongolian milk vetch were identified as Mesorhizobium metallidurans and M. ciceri (rrs homology to typical strains STM2683T and NBRC100389T was 100 and $99.6 \%$, respectively).

Figure 2 shows the rrs-phylogram demonstrating the taxonomic position of 9 slow-growing Rhizobium isolates within the Bradyrhizobiaceae family. Strains $1 / 11 \mathrm{M}, 3 / 6 \mathrm{M}, 3 / 11 \mathrm{C}, 3 / 21(2)$, and $12 / 11(1)$ isolated from various plants formed cluster IV with typical strain Tardiphaga robiniae LMG26467T and were assigned to this species ( $r r s$ index of similarity of 99.8-99.9\%). Cluster V with the level of statistical support of $99.0 \%$ was formed by four strains $3 / 5 \mathrm{M}, 3 / 31 \mathrm{~K}$, $12 / 22 \mathrm{M}$, and $3 / 25$ and two typical Bosea (B. lathyri and B. vaviloviae) strains. The rrs similarity of isolates to typical strains $B$. lathyri LMG26379T and B. vaviloviae Vaf-18T was 98.4-99.4 and 99.4-100\%, respectively. It should be noted that species $B$. vaviloviae was described as recently as 2015 for three microsymbiont strains of a relic legume Vavilovia formosa which grows in North Ossetia [17]. Therefore, Baikal isolates belonging to genus Bosea and having a high index of similarity to species $B$. vaviloviae are of great interest for further study.

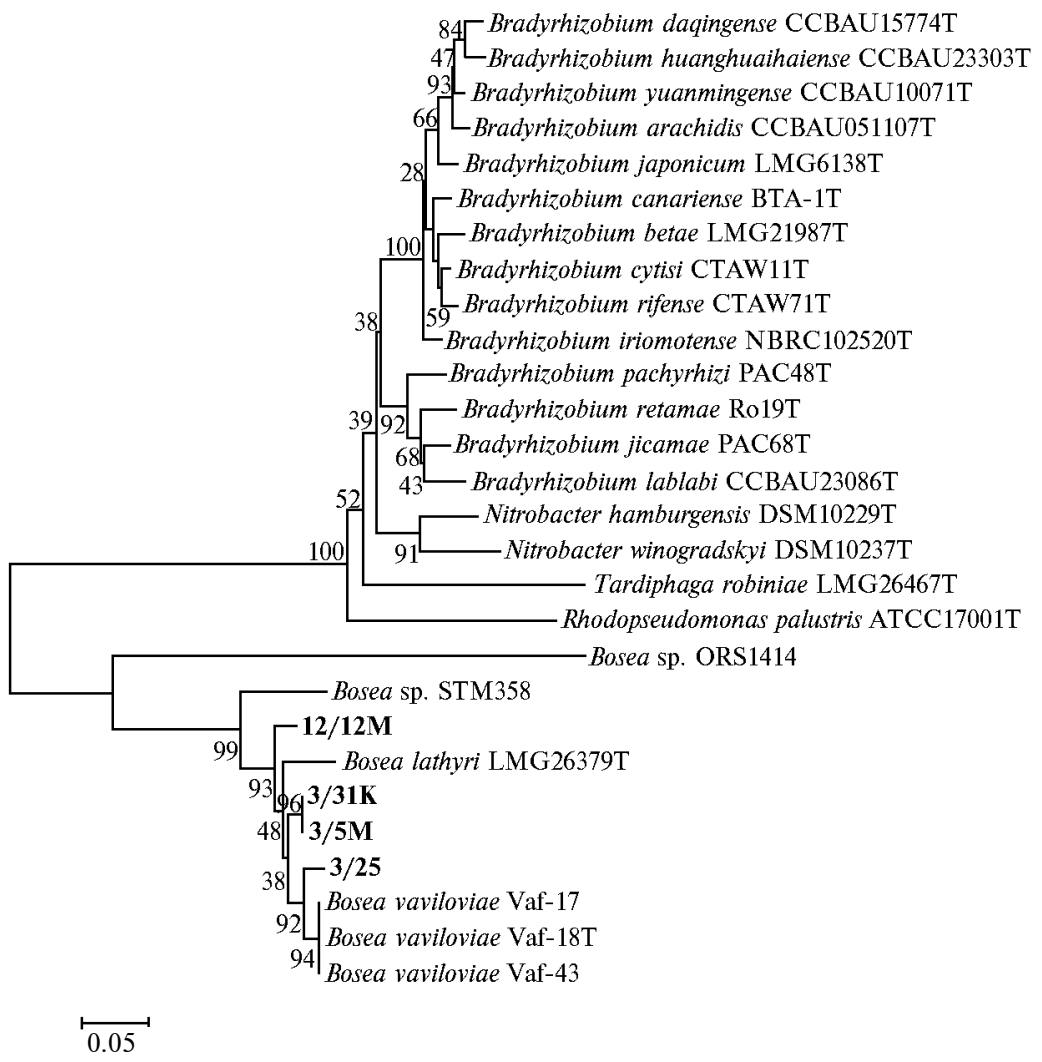

Fig. 3. ITS-phylogram demonstrating the taxonomic position of genera Bosea isolates isolated from Mongolian milk vetch (Astragalus mongholicus) and forest oxytrope (Oxytropis sylvatica) nodules. Tested strains are marked in bold. Letter «T» marks typical strains.

ITS-region sequencing was performed in strains $3 / 5 \mathrm{M}, 3 / 31 \mathrm{~K}, 12 / 22 \mathrm{M}$, and $3 / 25$ as this method provides higher resolution in the identification of closely related strains than rrs sequencing [9]. The dendrogram shown in Figure 3 demonstrates the correlation between the results of rrs and ITS-region sequencing. All isolates could be clustered with typical strains B. lathyri LMG26379T and B. va- 
viloviae Vaf-18T under the statistical support level of 99.0\%. However, the maximum levels of ITS-region homology between these isolates and typical strains B. lathyri and B. vaviloviae were low (of 84.9 and $89.4 \%$, respectively). Isolate $3 / 25$ was an exception, its ITS-region similarity to typical strain $B$. vaviloviae Vaf-18T was $97.8 \%$. Based on the results of rrs ITS-region sequencing, it was assigned to species $B$. vaviloviae. The taxonomic position of the other Bosea isolates is unclear as it is considered that nodule bacteria strains belonging to one species can not be less than $95 \%$ homologous in ITS-region [9]. Analysis of rrs sequencing in other Baikal isolates revealed their belonging to genera Herbiconiux (4 strains), Leifsonia (2 strains), Burkholderia (2 strains), Stenotrophomonas (2 strains), and Phyllobacterium (1 strain). Reported in the literature, some species of these genera may be present in legume nodules [18, 19] and be inhabitants of rhizosphere or phyllosphere of different plants.

Thus, rhizobial strains belonging to species Rhizobium spp., Mesorhizobium ciceri, Tardiphaga robiniae, and species of genus Herbiconiux (family Microbacteriaceae) can be found among the low-growing vetchling microsymbionts. Species of genera Mesorhizobium, Bosea, Tardiphaga, Leifsonia, Burkholderia and Stenotrophomonas were found among Mongolian milk vetch symbionts. Isolates of species $R$. leguminosarum bv. trifolii, T. robiniae and Bosea sp. were obtained from forest oxytrope nodules. A total of 40 strains belonging to species $R$. leguminosarum bv. trifolii were isolated from Baikal pea nodules, as well as one Phyllobacterium and one Burkholderia species. We would like to note that the presence of atypical rhizobial microsymbionts in legume nodules (M. ciceri and T. robiniae in vetchling; Bosea spp. and T. robiniae in milk vetch and oxytrope; Phyllobacterium sp. in pea) may indicate the active formation of relationships between partners in the legume-rhizobial systems of Baikal region.

\section{REFERENCES}

1. Tikhonovich I.A., B or is ov A.Yu., Tsyganov V.E. Uspekhi sovremennoi biologii, 2005, 125(3): 227-238.

2. Krasnaya kniga KhMAO - Yugry. Vstrechi s zhivotnymi i rasteniyami, 2015 [The Red Book of Khanty-Mansiysk - Yugra. Meeting with animals and plants] (http://animals.ecougra.ru).

3. Choi I.-S., Choi B.-H. Isolation and characterization of ten microsatellite loci from Korean Astragalus mongholicus (Fabaceae). J. Genet., 2013, 92: 73-76 (http//www.ias.ac.in/jgenet/OnlineResources/92/e73.pdf).

4. $\mathrm{K} \mathrm{u} \mathrm{z}$ ' $\mathrm{m}$ i n a E.A. Klonal'noe mikrorazmnozhenie astragala mongol'skogo (Astragalus mongholicus Bge.) [Clonal micropropagatin of Astragalus mongholicus Bge.]. Moscow, 2012 (http://www.rusnauka.com/29_NIOXXI_2012/Biolo-gia/11_117925.doc.htm).

5. Polozhi i V.A., Vydrina S.N., Kurbatski i V.I., Nikiforova O.D. Flora Sibiri. Tom 9 Fabaceae (Leguminosae) [Flora of Siberia. V. 9. Fabaceae (Leguminosae)]. Novosibirsk, 1994.

6. G a o J., Te r e f e w o rk Z., Che n W., Lind strom K. Genetic diversity of rhizobia isolated from Astragalus adsurgens growing in different geographical regions of China. J. Biotechnol., 2001, 91: 155-168 (doi: 10.1016/S0168-1656(01)00337-6).

7. Laguerre G., van Berkum P., A marger N., Prevost D. Genetic diversity of rhizobial symbionts isolated from legume species within the genera Astragalus, Oxytropis, and Onobrychis. Appl. Environ. Microbiol., 1997, 63(12): 4748-4758.

8. W d o wi a k S., Ma le k W. Numerical analysis of Astragalus cicer microsymbionts. Curr. Microbiol., 2000, 41: 142-148 (doi: 10.1007/s002840010108).

9. S afronova V.I., Chizhevskaya E.P., B elimov A.A., Pavlova E.A. Sel'skokhozyaistvennaya biologiya [Agricultural Biology], 2011, 3: 61-64 (http://www.agrobiology.ru/3-2011 pavlova.html).

10. Drouin R., Prevost D., Antoun H. Physiological adaptation to low temperatures of strains of Rhizobium leguminosarum bv. viciae associated with Lathyrus spp. FEMS Microbiol. Ecol., 2000, 32: 111-120 (doi: 10.1111/j.1574-6941.2000.tb00705.x).

11. Drouin R., Prevost D., Antoun H. Classification of bacteria nodulating Lathyrus japonicus and Lathyrus pratensis in Northern Quebec as strains of Rhizobium leguminosa- 
rum biovar viciae. Int. J. Syst. Bacteriol., 1996, 46(4): 1016-1024 (doi: 10.1099/0020771346-4-1016).

12. Van Cauwenberghe J., Verstraete B., Lemaire B., Lievens B., Michiels J., Honnay O. Population structure of root nodulating Rhizobium leguminosarum in Vicia cracca populations at local to regional geographic scales. Syst. Appl. Microbiol., 2014, 37(8): 613-621 (doi: 10.1016/j.syapm.2014.08.002).

13. Z h a ng R.J., Hou B.C., Wang E.T., Li Y. Jr., Zhang X.X., Che n W.X. Rhizobium tubonense sp. nov., isolated from root nodules of Oxytropis glabra. Int. J. Syst. Evol. Microbiol., 2011, 61(3): 512-517 (doi: 10.1099/ijs.0.020156-0).

14. Novikova N., S a fro nova V. Transconjugants of Agrobacterium radiobacter harbouring sym genes of Rhizobium galegae can form an effective symbiosis with Medicago sativa. FEMS Microbiol. Lett., 1992, 93: 261-268 (doi: 10.1016/0378-1097(92)90472-Z).

15. Rumyantseva M.L., S i marov B.V., Onishchuk O.P., Andronov E.E., Chizhevskaya E.P., Belova V.S., Kurchak O.N., Muntyan A.N., Rumyantseva T.B., Z atovskaya T.V. Biologicheskoe raznoobrazie kluben'kovykh bakterii $v$ ekosistemakh $i$ agrotsenozakh. Teoreticheskie osnovy i metody [Nodule bacteria biodiversity in ecosystems and agrocenoses. Theretical basis and methods]. St. Petersburg, 2011.

16. A marge $\mathrm{r}$ N., $\mathrm{Mach}$ eret V., Lague $\mathrm{rre}$ G. Rhizobium gallicum sp. nov. and Rhizobium giardinii sp. nov. from Phaseolus vulgaris nodules. Int. J. Syst. Bacteriol., 1997, 47(4): 996-1006 (doi: 10.1099/00207713-47-4-996).

17. Safronova V.I., Kuznetsova I.G., S a z a nova A.L., Kimeklis A.K., Belimov A.A., Andronov E.E., Pinaev A.G., Chizhevskaya E.P., Pukhaev A.R., P op ov K.P., Wi $11 \mathrm{e} \mathrm{m} \mathrm{s} \mathrm{A.,} \mathrm{Tik} \mathrm{ho} \mathrm{novich} \mathrm{I.A.} \mathrm{Bosea} \mathrm{vaviloviae} \mathrm{sp.} \mathrm{nov.} \mathrm{a} \mathrm{new} \mathrm{species}$ of slow-growing rhizobia isolated from nodules of the relict species Vavilovia formosa (Stev.) Fed. Antonie van Leeuwenhoek, 2015, 107: 911-920 (doi: 10.1007/s10482-015-0383-9).

18. Sardoso J.D., Hungria M., Andrade D.S. Polyphasic approach for the characterization of rhizobial symbionts effective in fixing $\mathrm{N}_{2}$ with common bean (Phaseolus vulgaris L.). Appl. Microbiol. Biotechnol., 2012, 93: 2035-2049 (doi: 10.1007/s00253-011-3708-2).

19. Le i X., Wang E.T., Che n W.F., Su i X.H., Chen W.X. Diverse bacteria isolated from root nodules of wild Vicia species grown in temperate region of China. Microbiology, 2008, 190(6): 657-671 (doi: 10.1007/s00203-008-0418-y).

20. Qiu F., Huang Y., Sun L., Zhang X., Liu Z., Song W. Leifsonia ginsengi sp. nov., isolated from ginseng root. Int. J. Syst. Evol. Microbiol., 2007, 57(2): 405-408 (doi: 10.1099/ijs.0.64487-0).

21. Behrendt U., S chumann P., Ha mada M., Suzuki K., Spröer C., Ulrich A. Reclassification of Leifsonia ginsengi (Qiu et al. 2007) as Herbiconiux ginsengi gen. nov., comb. nov. and description of Herbiconiux solani sp. nov., an actinobacterium associated with the phyllosphere of Solanum tuberosum L. Int. J Syst. Evol. Microbiol., 2011, 61(5): 1039-1047 (doi: 10.1099/ijs.0.021352-0). 